\title{
Neonatal Hyperthyroidism Alters Hepatic Epidermal Growth Factor Receptor Ontogeny in Mice
}

\author{
J. ALM, J. LAKSHMANAN, S. HOATH, AND D. A. FISHER \\ Department of Pediatrics, Karolinska Institute, St. Goran's Children's Hospital, Stockholm, Sweden [J.A.]; and \\ Department of Pediatrics, UCLA School of Medicine, Harbor UCLA Medical Center, Torrance, CA 90509
}

\begin{abstract}
Epidermal growth factor (EGF) liver receptor ontogeny and somatic growth were studied in mice from day 7 to day 70 postnatally to assess long-term effects of short-term postnatal thyroxine treatment. The mice were given $0.4 \mu \mathrm{g}$ thyroxine/g body weight/day for the $1 \mathrm{st}$ wk of life. EGF receptor binding in liver tissue was studied on days $7,15,20,30$, and 70 postnatally. Treated animals had accelerated eyelid opening and tooth eruption, and permanent growth retardation was obvious from the second week of life. Hepatic EGF receptor-binding capacity increased markedly in control mice with increasing age in contrast to a very slow increase in treated mice, making the difference statistically significant $(P<0.01)$ from day 30. The affinity of EGF receptor binding initially was similar in the two groups of animals $\left(1.09 \times 10^{9} \mathrm{M}^{-1}\right.$ and $\left.1.02 \times 10^{9} \mathrm{M}^{-1}\right)$ and increased by day 30 in controls $(2.57$ $\left.\times 10^{9} \mathrm{M}^{-1}\right)$, an increase that was not observed in treated animals either at day 30 or 70 . These results suggest a sensitive period of imprinting during the first 7 days postnatally, a period when thyroxine can exert a permanent effect on later growth and later hepatic EGF receptor number. (Pediatr Res 23: 557-560, 1988)
\end{abstract}

\section{Abbreviations}

EGF, epidermal growth factor

$T_{4}$, thyroxine

TSH, thyroid-stimulating hormone

Thyroid hormones are necessary for postnatal growth and development in rodents as in humans although the mechanism of the thyroid hormone effect is not entirely clear (1). Recent studies suggest that thyroid hormone interaction with specific growth factors may be important for normal postnatal growth and development (2). An interaction with the growth hormonesomatomedin axis has been described (2). Several other growth factors have been studied, but to date the interaction between thyroid hormones and EGF is the best characterized $(3,4)$. EGF is a polypeptide (mouse EGF mol. wt. 6045) first described in extracts from mouse submandibular glands (5-7). In vivo, EGF elicits precocious tooth eruption and eyelid opening in rodents, accelerates lung maturation in lambs and reduces gastric acid secretion in man (4-9). EGF binds to specific plasma membrane receptors that are found in many tissues and significant EGF binding to embryonal tissues has been reported $(7,10-14)$.

Received July 10, 1987; accepted January 25, 1988.

Correspondence Delbert A. Fisher, M.D. Professor of Pediatrics and Medicine, Harbor-UCLA Medical Center, 1000 West Carson Street, Torrance, CA 90509.

J.A. was a research fellow at the Department of Pediatrics, Harbor-UCLA Medical Center, supported by grants from Silbert International Scholars program, UCLA and Savstaholmsforeningen, Sweden.
An early indication of a close relation between thyroid hormones and EGF was found by Hamburgh et al. (15) who showed that the delay of eyelid opening and tooth eruption observed in hypothyroid animals was reversed by either thyroxine or EGF administration. Further studies suggest that synthesis of both EGF and its receptor protein are influenced by thyroid hormones $(3,4,12,16-20)$. Recent studies of early postnatal $\mathrm{T}_{4}$ treatment (0-6 days) of newborn mice have shown a prolonged effect of the $\mathrm{T}_{4}$ on tissue and urine EGF levels and a prolonged effect on growth (21). This effect was not observed in mice treated only during the 2 nd wk of life (21). The present study was undertaken to relate the disturbances in somatic growth to the postnatal ontogeny of liver EGF receptors in mice given exogenous thyroxine during the first week of life.

\section{MATERIALS AND METHODS}

Experienced female time-mated Swiss Webster mice were purchased from Simonsen Laboratories, Gilroy, CA. Each litter was set to eight pups immediately after delivery. Half of the litter was treated with $\mathrm{T}_{4} 0.4 \mu \mathrm{g} / \mathrm{g}$ body weight once daily sc; the other half served as controls and were injected with alkaline saline vehicle. Injections were begun on the day of delivery (day 0 ) and continued to day 6 . The animals were weaned on day 24 and maintained four animals per cage thereafter. They were weighed periodically and eyelid opening and tooth eruption were recorded. The mice were killed by $\mathrm{CO}_{2}$ narcosis on day $7,15,20$, and 30 or day 70; only female pups were included for study. There were eight treated and eight control pups in each age group.

Liver tissues were collected, immediately frozen on dry ice, and stored at $-70^{\circ} \mathrm{C}$ until further processing. Protein measurements were done according to Petersen (22). Liver samples were processed for receptor studies according to Hoch and Hollenberg (23). In short, the tissue was homogenized with a glass Teflon homogenizer in (wt/vol 1/10) $0.25 \mathrm{M}$ sucrose, $25 \mathrm{mM}$ Tris- $\mathrm{HCl}$ buffer with addition of trypsin inhibitor (Sigma Chemical Co., St. Louis, MO) $1 \mathrm{mg} / \mathrm{ml}$. The homogenate was spun at $600 \times g$ for $10 \mathrm{~min}$. The pellet was discharged, the supernatant was respun at $10,000 \times g$ for $30 \mathrm{~min}$, and the second pellet was discarded. The supernatants were made $0.1 \mathrm{M}$ in $\mathrm{NaCl}$ and $0.2 \mathrm{mM}$ in $\mathrm{MgSO}_{4}$ [by adding $1 / 10(\mathrm{vol} / \mathrm{vol})$ of a solution of $0.25 \mathrm{M}$ sucrose, $25 \mathrm{mM}$ Tris- $\left.\mathrm{HCl}, 1.01 \mathrm{M} \mathrm{NaCl}, 2.02 \mathrm{mM} \mathrm{MgSO}_{4}\right]$, and spun at $48,000 \times g$ for $45 \mathrm{~min}$. The pellets were resuspended in Tris- $\mathrm{HCl}$ buffer, respun at $48,000 \times g$ for $45 \mathrm{~min}$ and finally rehomogenized in $0.05 \mathrm{M}$ phosphate buffer $(1 \mathrm{ml} / 250 \mathrm{mg}$ of original liver tissue). These preparations were stored at $-70^{\circ} \mathrm{C}$ for EGF receptor analysis.

EGF used for radioreceptor analysis was purchased from Collaborative Research (Lexington, MA). EGF was iodinated using the Chloramine-T method (24) to achieve a specific activity between 250 and $300 \mathrm{cpm} / \mathrm{pg}$ of EGF. The specific activity of labeled EGF was determined using a double antibody, liquid 
phase EGF radioimmunoassay previously described (3). EGF binding studies were carried out in $12 \times 75$ polystyrene tubes in a 200-300 $\mu \mathrm{l}$ reaction volume containing: $0.05 \mathrm{M}$ phosphate buffer with $1 \%$ (wt/vol) bovine albumin, $100 \mu \mathrm{g}$ of liver membranes, and ${ }^{125} \mathrm{I}$-EGF. Incubations were carried out at $24^{\circ} \mathrm{C}$ for $45 \mathrm{~min}$. Incubation time below $35 \mathrm{~min}$ and above $60 \mathrm{~min}$ decreased EGF binding. Samples were diluted with $4 \mathrm{ml}$ of ice cold buffer $[0.05 \mathrm{M}$ phosphate buffer with $1 \%$ (wt/vol) bovine albumin], filtered through a Millipore filter (GF/C $1.2 \mu \mathrm{m})$ using a multiple manifold apparatus and rapidly washed with two 4$\mathrm{ml}$ aliquots of ice cold buffer under reduced pressure $(100 \mathrm{~mm}$ $\mathrm{Hg}$ ). The radioactivity retained in the filter was measured in a gamma scintillation counter.

Radioactivity bound in the presence of an excess $(5 \mu \mathrm{g} /$ tube) of cold EGF was defined as nonspecific binding (1-2\% of added label). Specific binding was calculated by substracting nonspecific binding from the total amount bound. EGF binding in liver tissues from individual animals was assessed in duplicate with $100 \mathrm{~g}$ of membrane protein in $200 \mu \mathrm{l}$ reaction volume with labeled EGF to achieve a free concentration of labeled EGF of $0.6 \mathrm{nM}$. For estimating affinity by the method of Scatchard (25), $100 \mu \mathrm{g}$ of membrane protein in triplicate were added to a final volume of $300 \mu \mathrm{l}$ with increasing amounts of cold EGF $(0.09-$ $50 \mathrm{nmol}$ ) in the presence of a tracer amount of labeled EGF $(25,000 \mathrm{cpm})$. A best fit regression line was computer generated for the individual scatchard data. The affinity constant was calculated from the slope of the regression line. Maximal binding capacities were calculated as the intercept of the regression line and the horizontal axis.

The Student's $t$ test was used for comparison of individual binding data. Results are recorded as mean and SD unless indicated otherwise.

\section{RESULTS}

Tooth eruption and eyelid opening were significantly accelerated in treated animals compared to controls. Tooth eruption occurred on day $6.6 \pm 0.49$ (mean \pm SD) in treated animals versus day $9.9 \pm 1.1$, for controls $(p<0.01)$. Eyelid opening occurred on day $12.0 \pm 0.81$ in treated animals versus day 13.6 \pm 0.74 for controls $(p<0.01)$. The decreased growth rate in treated animals resulted in a significantly lower body weight from day 8 in treated animals $(p<0.01)$ compared to controls (Fig. 1).

Hepatic EGF binding data from control and treated animals are shown in Figure 2. The binding of EGF to liver membranes was similar in control and treated animals on days 7,15 , and 20 and significantly different $(p<0.01)$ on days 30 and 70 in treated compared to control mice (Fig. 2). Scatchard analyses were

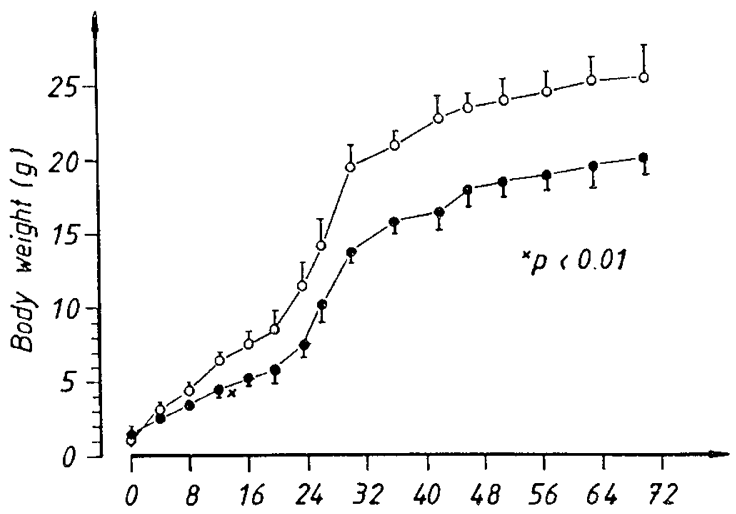

Fig. 1. Body weight in eight treated and eight control animals (open circles) followed from birth to 70 days of age. Age in days is plotted on the horizontal axis. Values are shown as mean and SD. The difference in weight becomes significant $(P<0.01)$ at 12 days $(\mathrm{x})$. conducted on liver samples from day 7 (samples from all animals in each group pooled), and days 30 and 70 (animals pooled two and two) (Fig. 3 and 4). On day 7 binding capacity and binding affinity were of the same magnitude in control and treated animals (1.09 versus $1.02 \times 10^{9} \mathrm{M}^{-1}$ and 0.64 versus $0.76 \mathrm{ng} /$ mg protein, respectively, Table 1). Among control animals an increase in high affinity receptor binding was observed with age, an increase not observed in treated animals (Table 1). Thus, EGF binding affinities in control animals were significantly higher than in treated animals at 30 days (1.06 versus $2.57 \times 10^{9}$ $\left.\mathrm{M}^{-1}\right)$ (Fig. 4; Table 1). The statistically higher $\mathrm{B}_{\max }$ values $(p<$ 0.05 ) in control animals on day 30 (Table 1) are evident as well on the horizontal axis of Figure 4 . When binding was assessed in individual 70-day-old animals, there was significantly reduced

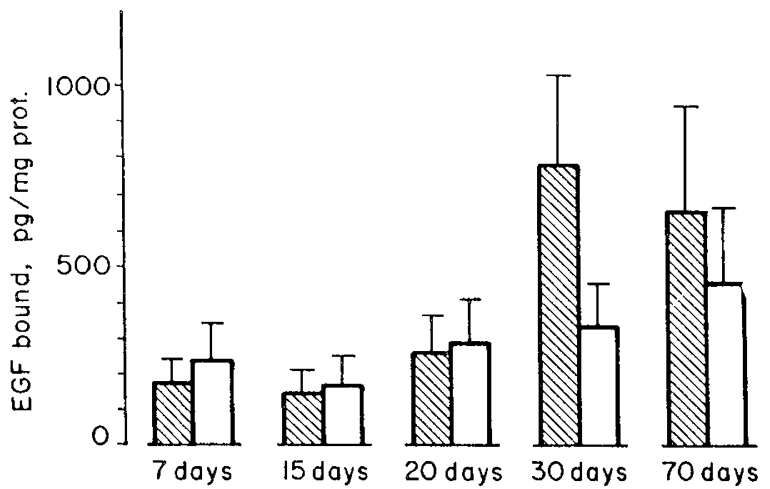

Fig. 2. EGF binding in liver membrane homogenates from individual animals at 7,15,20,30, and 70 days of age. Open bars, treated animals; hatched bars, control animals. Values plotted as mean and SD.

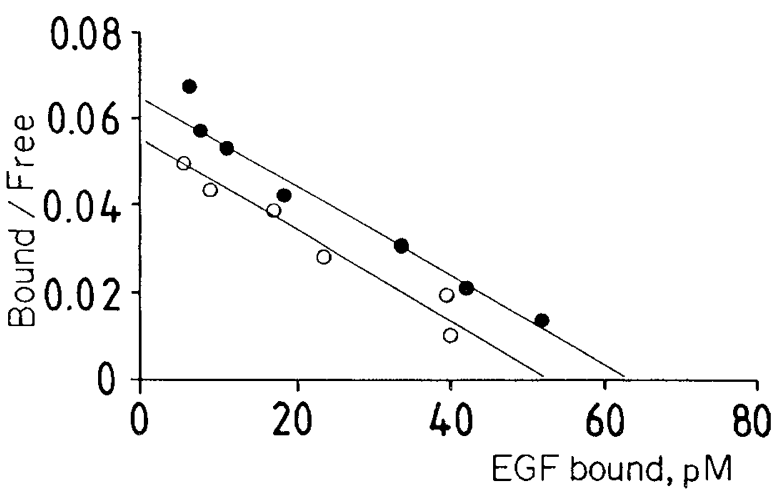

Fig. 3. Scatchard analysis of control animals at 7 days of age (open circles) and of treated animals at 7 days of age (closed circles).

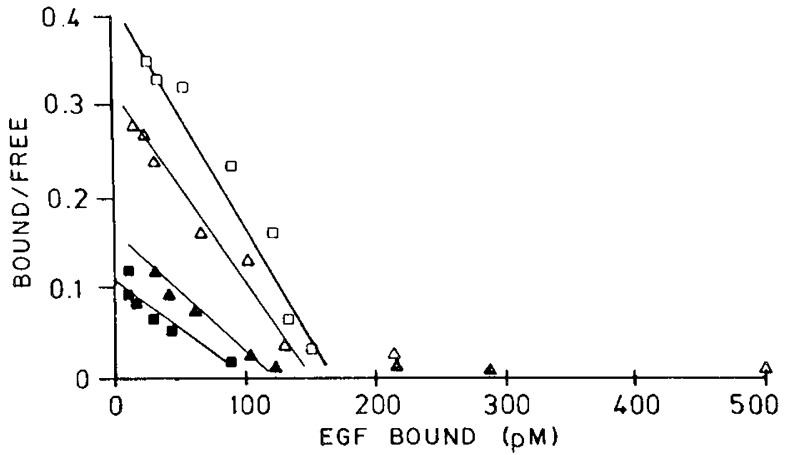

Fig. 4. Scatchard analysis of control animals at 30 days of age (open squares) and 70 days of age (open triangles), and of treated animals at 30 days of age (solid squares) and of 70 days of age (solid triangles). 
Table 1. Average hepatic EGF receptor maximal binding capacities $\left(B_{\max }\right)$ and affinity constants $(\mathrm{Ka})^{*}$

\begin{tabular}{|c|c|c|c|c|}
\hline \multirow[b]{2}{*}{ Age (days) } & \multicolumn{2}{|c|}{$\mathrm{B}_{\max }(\mathrm{ng} / \mathrm{mg}$ protein $)$} & \multicolumn{2}{|c|}{$\mathrm{Ka}\left(10^{9} \mathrm{M}^{-1}\right)$} \\
\hline & Controls & Treated & Controls & Treated \\
\hline 7 & 0.64 & 0.76 & 1.09 & 1.02 \\
\hline 30 & $2.07 \pm 0.31$ & $1.32 \pm 0.29 \dagger$ & $2.57 \pm 0.39$ & $1.06 \pm 0.22 \dagger$ \\
\hline 70 & $1.93 \pm 0.40$ & $1.45 \pm 0.38$ & $2.02 \pm 0.31$ & $1.12 \pm 0.37$ \\
\hline
\end{tabular}

* Values as mean and SD. See text for details; 7-day values represent pooled samples.

$\dagger p<0.05$ treated versus controls.

binding in treated as compared to control animals. However, when these animal samples were pooled (two and two) to develop data for Scatchard plots, there were no differences in affinity and binding capacity (2.02 versus 1.12 and 1.93 versus $1.45 \times 10^{9}$ $\mathbf{M}^{-1}$, respectively, Fig. 4 , Table 1 ).

\section{DISCUSSION}

Herein we observed the expected effect of thyroxine treatment during the 1 st wk of life on eyelid opening and tooth eruption. Also, the treated mice showed a long-term growth retardation as reported earlier (Fig. 1) (21). In addition, hepatic EGF-binding capacity and affinity were significantly reduced on day $30 \mathrm{com}$ pared to values in control animals. In control animals there was an increase in maximal binding capacity and binding affinity of hepatic EGF receptors between 20 and 30 days (Table 1; Figs. 2 and 4). In the treated animals at 30 days both parameters remained at lower, immature levels (Table 1; Fig. 4). In other studies of normal control animals two populations of hepatic EGF receptors have been observed $(11,26)$. We were not able to show the presence of two receptor populations in our study. However, the increase in affinity observed with age is most probably due to an increase of a high affinity receptor and not due to a change of individual receptor affinity.

There is considerable evidence supporting a thyroid hormone dependency of EGF receptors. EGF receptor binding has been shown to increase in response to thyroid hormone treatment in mouse skin and rat liver $(12,18,19)$, and congenitally hypothyroid mice fail to show the postnatal increase in hepatic EGF binding normally observed between 20 and 30 days (26). In the present control animals the expected increase of hepatic EGF receptor binding was observed, whereas the animals treated neonatally with thyroxine had no increase (Figs. 2 and 4). In this regard they resemble hypothyroid animals.

Other late abnormalities were observed in mice treated with thyroxine for the first 6 days of life. Growth retardation was obvious in our animals (Fig. 1) and it has been shown that this effect persists in adulthood (27-29). Impaired pituitary growth, decreased pituitary TSH concentrations, increased hypothalamic thyroid-releasing hormone levels, decreased TSH responsiveness to propylthiouracil challenge, and delayed puberty also have been reported (28) as well as a significantly reduced serum TSH level and increased pituitary iodothyronine $5^{\prime}$ monodeiodinase activity (29). Thus, permanent dysfunction at both the hypothalamic and pituitary levels occurs $(28,29)$. An altered set point for $\mathrm{T}_{4}$ feedback control has been postulated based on the altered level of pituitary iodothyronine $5^{\prime}$ monodeiodinase activity. Serum EGF concentrations also are elevated at 30 days in mice treated neonatally with $\mathrm{T}_{4}$ although submandibular gland EGF concentrations are reduced (21). Whether the altered EGF metabolism/ontogenesis is related to the growth retardation is not clear.

The present observations in combination with earlier studies indicate that neonatal $\mathrm{T}_{4}$ treatment of mice or rats permanently alters growth and alters tissue EGF ontogenesis and EGF receptor metabolism $(21,28,29)$. These parameters seem to be imprinted by the prevailing $\mathrm{T}_{4}$ level during early postnatal life. Hormonal imprinting during a critical, usually perinatal, period of development is a well-characterized phenomenon. In the rodent, neonatal androgen administration produces permanent alterations of hypothalamic regulation of pituitary gonadotropin secretion, adult behavior, and adult sexual activity as well as the patterns of growth hormone secretion, body growth, and hepatic steroid metabolism (30-33). Neonatal administration of alloxan or insulin to rats has been reported to produce permanent alterations of glucose tolerance, and neonatal vasopressin treatment alters adult vasopressin responsiveness (34-37). The mechanism(s) of hormonal "imprinting" however is not clear. Permanent effects on brain structure have been demonstrated (32) and a permanent alteration of developing, transiently "plastic" receptors has been proposed $(33,37)$. Interestingly, the imprinting effect in some instances has been observed to be transmitted to subsequent generations of rodents $(28,34,37)$.

\section{REFERENCES}

1. Schwartz HL 1983 Effect of thyroid hormone on growth and development. In Oppenheimer JA, Samuels HH (eds) Molecular Basis of Thyroid Hormone Action. Academic Press, New York, pp 413-444

2. Fisher DA, Hoath SB, Lakshmanan J 1982 The thyroid hormone effects on growth and development may be mediated by growth factors. Endocrinol Exp 16:259-271

3. Hoath SB, Lakshmanan J, Scott SM, Fisher DA 1983 Effect of thyroid hormones on epidermal growth factor concentrations in neonatal mouse skin. Endocrinology 112:308-314

4. Lakshmanan J, Perheentupa J, Macaso T, Fisher DA 1985 Acquisition of urine, kidney and submandibular gland epidermal growth factor responsiveness to thyroxine administration to neonatal mice. Acta Endocrinol 109:511 516

5. Cohen S 1962 Isolation of a mouse submaxillary gland protein accelerating incisor eruption and eyelid opening in newborn animals. $\mathrm{J}$ Biol Chem 237:1555-1562

6. Cohen S, Carpenter S 1975 Human epidermal growth factor: isolation and chemical and biological properties. Proc Natl Acad Sci USA 72:1317-1321

7. Carpenter G, Cohen S 1979 Epidermal growth factor. Annu Rev Biochem 48:193

8. Catterton WZ, Escobedo MB, Sexson WR, Greys ME, Sundell W, Stahlman MJ 1979 Effect of epidermal growth factor on lung maturation in fetal rabbits. Pediatr Res 13:104-108

9. Gregory H 1975 Isolation and structure of urogastrone and its relationship to epidermal growth factor. Nature 257:325-327

10. Cohen S, Ushiro H, Chinkers M 1982 A native 170,000 epidermal growth factor receptor-kinase complex from shed plasma membrane vesicles. J Biol Chem 127:1523-1531

11. Adamson ED, Rees AR 1981 Epidermal growth factor receptors. Mol Cell Biochem 34:129-152

12. Hoath SB, Lakshmanan J, Fisher DA 1985 Epidermal growth factor binding to neonatal mouse skin explants and membrane preparations-effects of triiodothyronine. Pediatr Res 19:277-280

13. Adamson ED, Meek J 1984 The ontogeny of epidermal growth factor receptors during mouse development. Dev Biol 105:62-70

14. Hoch R, Nexo E, Hollenberg MD 1979 Isolation of the human placental receptor for epidermal growth factor-urogastrone. Nature 277:463-465

15. Hamburgh M, Mendoza LA, Burbart JR, Weil F 1971 Thyroid dependent processes in the developing nervous system. In: Hamburg M, Mendoza LA (eds) Hormones in Development. Appleton Century Crafts, New York, pp 403-415

16. Hoath SB, Lakshmanan J, Fisher DA 1984 Thyroid hormone effects on skin and hepatic epidermal growth factor concentration in neonatal and adult mice. Biol Neonate 45:49-52

17. Gresik EW, Schenbein J, van der Voen H, Barba T 1981 Hormonal regulation of epidermal growth factor and protease in the submandibular gland of the adult mouse. Endocrinology 109:924-929

18. Hayden LG, Severson DL 1983 Correlation of membrane phosphorylation and epidermal growth factor binding to hepatic membranes isolated from triiodothyronine treated rats. Biochem Biophys Acta 850:226-230

19. Mukku VR 1984 Regulation of epidermal growth factor receptor levels by thyroid hormones. J Biol Chem 259:6543-6547

20. Perheentupa J, Lakshmanan J, Fisher DA 1984 Epidermal growth factor in neonatal mouse urine: maturative effect of thyroxine. Pediatr Res 18:1080 1084

21. Lakshmanan J, Perheentupa J, Alm J, Fisher DA 1986 Neonatal hyperthyroidism in mice has different effects on epidermal growth factor levels in submandibular gland, urine and blood. Pediatr Res 20:628-631

22. Petersen CL 1977 A simplification of the protein assay method by Lowry et al which is more generally applicable. Ann Biochem 83:346-356

23. Hoch R, Hollenberg MD 1980 Characterization of the receptor for epidermal growth factor-urogastrone in human placenta membrane. J Biol Chem 255:10731-10736 
24. Greenwood FC, Hunter WM, Glover JS 1963 The preparation of ${ }^{131}$ I-labeled human growth hormone of high specific radioactivity. Biochem $\mathbf{J}$ 89:114124

25. Scatchard C 1947 The attraction of proteins for small molecules and ions. Proc NY Acad Sci USA 51:660-672

26. Alm J, Scott S, Fisher DA 1986 Epidermal growth factor receptor ontogeny in mice with congenital hypothyroidism. J Dev Physiol 8:377-385

27. Martin SM, Moberg GP 1981 Effects of early neonatal thyroxine treatment on development of the thyroid and adrenal axes in rats. Life Sci 29:1683-1688

28. Bakke JL, Laurence NL, Bennet J, Robinson S 1975 Endocrine syndromes produced by neonatal hyperthyroidism, hypothyroidism, or altered nutrition and effects seen in untreated progeny. In: Fisher DA, Burrow GN (eds) Perinatal Thyroid Physiology and Disease. Raven Press, New York, pp 79112

29. Walker P, Courtin F 1985 Transient neonatal hyperthyroidism results in hypothyroidism in the adult rat. Endocrinology 116:2246-2250

30. Barraclough CA 1961 Production of anovulatory, sterile rats by single injection of testosterone propionate. Endocrinology 68:62-67

31. Janson JO, Ekberg S, Isacksson O, Mode A, Gustavsson JA 1985 Imprinting of growth hormone secretions, body growth, and hepatic steroid metabolism by neonatal testosterone. Endocrinology 117:1881-1889

32. Gorski RA 1984 Sexual differentiation of brain structure in rodents. In: Serio M, Zanisi M, Martini L (eds) Sexual Differentiation: Basic and Clinical Concepts. Raven Press, New York, pp 65-77

33. Dohler KD 1987 The special case of hormonal imprinting, the neonatal influence of sex. In: Csaba G (ed) Development of Hormone Receptors. Birkhauser Verlag, Basel, pp 103-123

34. Speigel G, Levy LJ, Goldner MG 1971 Glucose intolerance in the progeny of rats treated with single subdiabetogenic dose of alloxan. Metabolism 20:401413

35. Csaba G, Inczefi-Gonda A, Dobozy O 1984 Hereditary transmission in the $F_{1}$ generation of hormonal imprinting (receptor memory) induced in rats by neonatal exposure to insulin. Acta Physiol Hung 63:93-99

36. Csaba G, Ronai A, Laszlo V, Darvas ZS, Berzetei I 1980 Amplification of hormone receptors by neonatal oxytocin and vasopressin treatment. Horm Metab Res 12:28-31

37. Csaba G 1987 Receptor ontogeny and hormonal imprinting. In: Csaba G (ed) Development of Hormone Receptors. Birkhauser Verlag, Basal, pp 79-102 